\title{
The Effect of Working Climate, Team Effectiveness, Job Satisfaction and Normative Commitment OnPerformance Of Primary School Principals In Medan
}

\author{
Yusuf, Prof. Dr. Zainuddin, Prof. Dr. Abdul Hamid K. \\ ${ }^{1)}$ Post Graduated Program at State University of Medan; Trainer at Education Quality Assurance Agency \\ (LPMP)Medan, North Sumatera \\ ${ }^{2)}$ Professor at State University of Medan \\ ${ }^{3)}$ Professor at State University of Medan
}

\begin{abstract}
This study aims are to determine: (1) the influence of the working climate on job satisfaction of primary school principals in Medan; (2) the effect of the team's effectiveness on job satisfaction of primary school principals in Medan; (3) the effect on the working climate normative commitment of primary school principals in Medan; (4) the effect of the team's effectiveness against normative commitment of primary school principals in Medan; (5) working climate influence on the performance of primary school principals in Medan; (6) the effect of the team's effectiveness on the performance of primary school principals in Medan; (7) the effect of job satisfaction on the performance of primary school principals in Medan; and (8) the effect of normative commitment to the performance of primary school principals in Medan. Subjects research are primary schools principals in Medan with a total sample 272 principals. Sampling is done by random sampling method. The research method is path analysis to obtain the effect of exogenous variables on endogenous variables of the study. Based on hypothesis testing, It can be concluded: (1) there is a significant direct influence the working climate on job satisfaction of primary school principals in Medan at 14.4\%; (2) there is a significant direct effect the team's effectiveness on job satisfaction of primary school principals in Medan at 21.0\%; (3) there is a significant direct influence the working climate on the normative commitment of primary school principalsin Medan at $29.5 \%$; (4) there is a significant direct effect the team effectiveness on normative commitment of primary school principals in Medan at 23.7\%; (5) there is a significant direct influence the working climate on the performance of primary school principals in Medan at 13.3\%; (6) there is a significant direct effect between the team effectiveness on the performance of primary school principals in Medan at 16.8\%; (7) there is a significant direct effect between job satisfaction on the performance of primary school principals in Medan at $18.0 \%$; and (8) there is a significant direct effect normative commitment on the performance of primary school principals in Medan at 30.3\%. The results obtained by the working climate, team effectiveness, job satisfaction, and normative commitment on the performance of primary school principals in Medan.
\end{abstract}

Keywords:work climate, team effectiveness, job satisfaction, normative commitment, performance of primary school principals

\section{BACKGROUND}

Education plays a very important role to ensure the survival of the state and nation because education is one of the fundamental efforts in promoting and developing the quality of human resources. None of nation or country can move forward without advance the education first. The advancement of education will have a positive impact in improving human resources. Mulyasa (2011: 3) suggests the influence of education can be seen and felt directly in the development of community as well as community life, group life, and the individual life. Education deals directly with human formation. Education determines the human model that will result. Recognizing the importance of the process of improving the quality of human resources, the government continues to realize the mandate through various activities to build better quality education through seminars and school management tarining to policy makers at the school. Tannembaum in Wahjosumidjo (2011: 17) argues leadership is interpersonal influence exercised in a situation, and directed, through the communication process, toward the attainment of a specified goal. The same thing was stated Hasibuan (2007: 13) argued that leader is someone who uses the authority and leadership to direct other people and was responsible for that person's work in achieving a goal.

With the powerful role of the principal, the school achievement of the goals in creating a conducive learning environment, whether it is for teachers, administrators, and students. Yuniarsih and Suwatno (2009: 
165) said that one of the factors supporting the creation of high productivity is the role of a leader who is able to show leadership in a professional manner. Greefield (1987) stated that the indicators of a school principal in managing the school, in general it can be observed from: (1) a commitment to the vision of the school as a general guideline in carrying out his/her duties and functions; (2) make the vision of the school as a guide in managing and leading schools; and (3) continue to focus school activities on learning and teacher performance in the classroom. The existence of a leader even more important when faced with situations with a diversity of characteristics and capabilities of the members of the organization, but each still expected to be able to contribute meaningfully to the organization. Based on mapping the performance of principals which done by Board of Educational Human Resources Development and Quality Assurance of Education, Ministry of Education and Culture at 31 provinces (BPSDM-PMP, Kemdikbud). It showed that the social competence and supervision of the school principal is generally low. In the study the performance of the principal, the value of the dimensions of personal competence is 85 , the value of managerial competence is 74 , the value of supervision competence is 72 , and the value of social competence is 63 . The passing grade of the competence is 76 , then only the personal competence pass while other dimension of competency do not pass.

Governments take measurements to see how competent a school principal in developing the school led. The result of Performance Test Principal (UKKS) 2015 which was held on 23 to 28 March in 2015, the number of participants UKKS in North Sumatra province is 10.495 principals. Participants UKKS North Sumatra Province which mostly came from the city of Medan with the number of participants of 960 people while the least is Sibolga with the number of participants is 70 people. Average value achievements of UKKS at North Sumatra province is 41.30 on a scale of 0 - 100. This means that the level of performance of the principal in the province of North Sumatra is still very low and needs to the attention of education stakeholders at the district/city. The mean achievement of UKKS showed the poor performance of school principals at every level of the school and the lowest performance is the competence of primary school principals. The mean achievement levels of UKKS the principal of primary School (SD) in North Sumatra province was 38.924 on a scale of $0-100$, the average elementary school principal achievements in Medan is 41.63. This condition indicated that for the performance of the principal is still very low in the management of school education. This can backfire in the provincial government's efforts to improve the quality of education in North Sumatra.

Strengthening the ability of principals through the training program performance of the principal in carrying out their duties and functions as the policy of Minister of National Education is a program that can not be avoided. At least there are three points as background need to develop a program of strengthening the ability of the principal. First, the demand National Education Minister Regulation No. 13 of 2007 on the Standards for School/Madrasah, which contains the mandate that the school principal is the highest leadership in the school are required to have five dimensions of competence, namely: the dimensions of personal competence, managerial, entrepreneurial, supervision, and social, so gradual and continuous performance of the principal must be improved. Second, the community demands more and want to enhance the quality of learning in order to produce graduates who can compete, not only at local and national level, but also at the international level. People want to improve the quality of learning not only in order to prepare the sons and daughters follow the national exam, but also make the sons and daughters with life skills, such as critical thinking abilities, innovative, and creative. Third, the policy of the Minister of National Education, that the development of learning in the future focused on the development of learning that is expected to produce graduates who are creative, innovative, problems solving skilled, think critically, and has entrepreneurial spirit.

In school activities, the effectiveness of program depends on the leadership of a school principal. Some of the principal described as people who has high expectations for staff and students, principals are those who are highly knowledgeable of their duties and those who set the tone for their schools. As stated in Article 12 Paragraph 1 of Government Regulation 28 of 2005 that the principal is responsible for the implementation of educational activities, school administration, coaching, other education personnel and utilization and maintenance of facilities and infrastructure.

Many theories that examine the performance of a person, one theory put forward Colquitt, Jeffery, and Michael (2009: 9), a number of factors that affect performance and commitment, including individual mechanisms (job satisfaction, stress, motivation, trust, justice and etics, learning and decision making), individual characteristics (personality and cultures values, abilities), group mechanisms (team characteristics, team processes, power and leader influence, leader style and behaviors), and organizational mechanisms (organizational structure, organizational culture). Robbins (2007: 27) suggests the term is also known as human performance output that can be measured in: productivity, absence, turnover, citizenship, and satisfaction. It means that if the level of production, attendance rate, level of loyalty and satisfaction levels are high, it can be used as an assessment that the performance of the principal can be good or no.

School principals are required to have a high commitment that school objectives can be achieve. In performing their duties as the principal required a high commitment to carry out his duties as a leader in the school. Kreitner and Kinicki (2001: 75) suggested that a higher commitment to facilitate the realization of 
higher productivity. The research result Shah (2012) and Mahmood et al. (2011) revealed that there are significant effect commitment on the performance of teachers. Thus the commitment has influence to the performance of teachers.

Normative commitment of principal would grow in line with the increase in the effectiveness of teamwork at the school. Ullah research results and Dong (2013) and Lischshinsky and Vicki (2010) revealed that there is influence of the team effectiveness on personal commitment. With a good running team effectiveness success in performing the duties of school principals would be optimal. It can be said that the principal has a commitment to perform or manage classes with consistently will further improve the quality of work.

To achieve the goal of school need job satisfaction factors of principals. Blum in Aryanti (2003) suggested the job satisfaction is the general attitude that is the result of some special attitude towards factors work, adjustment and social relationships of individuals out of work. Usop research results, et al (2013) and Ali and Abdulkadir (2015) there are significant effect job satisfaction on performance. Gibson, John, and James (2000: 150) said job satisfaction is a positive attitude and can also negatively owned by individuals against various aspects of work, work and relationships with co-workers. In general, people are satisfied to work when he is happy doing the job at hand and carried out every day. Thus, the principal who has the job satisfaction will increase performance.

Job satisfaction is also influenced by the work climate. Harmonious working climate will affect the smooth implementation of the program of the organization. Tagiuri and Litwin in Wirawan (2008: 121) suggests working climate is the quality of the organization's internal environment relatively persist, taken by members of the organization; influence their behavior and can be described in terms of a set of characteristics or nature of the organization. Popa research results (2011) and Poonam Rani (2014), and Jayaweera (2015) showed that there is effect of climate on teacher performance.

Job satisfaction is also influenced by the team's effectiveness. Team is a working group established with the aim of a common goal to succeed an organization or community group. The results of the study Chen, et al (2011), Somech, et al (2009), Rico, et al (2011), which revealed there is influence team effectiveness on the organization's performance. Robbins and Judge (2008: 404) says that the team usually works better than individuals when the tasks do require a lot of skill, opinions, and experiences. The main objective is to build a team that solidarity work units that have identification for membership and strong cooperation. The background is expressed can be seen linkages between work climate, team effectiveness, job satisfaction, and normative commitment to the performance of the principal. Related to this, the most important research conducted research with the title: The Effects of Work Climate, Team Effectiveness, Job Satisfaction, and Normative Commitment on Performance of primary school principals in Medan.

\section{THEORITICAL REVIEW}

\section{Performance}

Performance issues in the management always gets attention because it is closely related to the productivity of the institution or organization. Hasibuan (1999: 126) described the performance has a close relationship with productivity issues, as an indicator in determining how the effort to achieve high levels of productivity in an organization. Colquitt, Lepine, and Wesson (2009: 9), the overall performance is affected by components: individual mechanisms, individual characteristics, mechanism group, and organizational mechanism. Miner (1997: 196) suggests performance has four aspects: (1) quality of the output, explains about the number of errors, timing, and accuracy in performing tasks; (2) The quantity produced, with regard to how many products or services that can be produced; (3) working time, will explain how the number of absences, tardiness, and working lives of the individuals that have been undertaken; and (4) cooperation, will explain how individuals help or hinder the effort from coworkers.In simple terms the principal is defined as a functional staff teachers are given the task to lead a school in which organized learning process or a place where there is interaction between the teacher who gave lessons and pupils who receive lessons. The success of principals indicate that the principal is the person who determines the center point and rhythm of a school. Even further concluded that school success is the success of the principal.

\section{Working Climate}

Working climate is defined as a psychological atmosphere that can affect the behavior of members of the organization, formed as a result of the actions of the organization and interaction among members of the organization to the work environment that formed in the work environment and affects their behavior in the work. Gibson, John, and James (2000: 69) stated work climate of an organization is the nature of the working environment or psychological environment in the organization perceived by workers or members of the organization and is considered to influence the attitudes and behavior of workers to work. Payne and Pugh in 
Steers and Porter (1985: 129) stated that the working climate is mainly attitudes, values, norms and common sense possessed by workers in connection with their organization.

\section{Team effectiveness}

Team is a working group established with the aim of succeeding the objective a group. It included motivating the members to feel pride in performing the task group. According to Pace and Faules (2000: 114), a working group is a team that responsible for the formation of a product or handle a process within the organization. Rival and Deddy (2011: 160) argued a team is a group of people with complementary skills and be committed to the same mission, achievement of performance, and approaches where they are interdependent each other. Through the cooperation of the team will be able to share knowledge and skills, so that a team is often able to complete these tasks effectively, rather than done by an individual. The role of a team is a group of people with complementary skills and be committed to the same mission, achievement of performance, and approach for which they are interdependent each other. The main objective of teamwork is to build a solidarity organization that has strong membership identification and strong membership and cooperation.

\section{Job satisfaction}

Job satisfaction is feeling happy or not happy is relatively different from thinking objectively and desire behavior. Spector in Smith (1983: 655) stated that job satisfaction is an attitude that reflects how people's feelings toward his work as a whole as well as on various aspects of his work. High satisfaction is desired by the principal because it can be associated with positive results they expected, which shows the educational management effectively and efficiently by the principal. The principals became actors who supports the achievement of the education goals, have thoughts, feelings and desires that can affect attitudes towards the job. Colquit, Lepine, and Wesson (2009: 105) stated job satisfaction is the level of pleasant feeling obtained from a person's job ratings or work experience. Robbins and Judge (2008: 114) gives the definition of job satisfaction as a positive feeling about the job as a result of the evaluation of characteristics. If principals feel satisfaction in the work, will show a positive attitude in the organization where he works for his needs fulfilled in accordance expectations, so they will tend to work in earnest and sacrifice for the sake of the organization in the form of enhancing their performance.

\section{Normative commitment}

A principals who have a high normative commitment would feel guilty if it delivers poor performance in leading the school. Stringer in Wirawan (2008: 133) argued commitment reflects a sense of pride members of the organization and the degree of loyalty to the achievement of organizational goals. The opinions above expressed commitment is an attitude that indicated a person in his responsibilities as a member of the organization.Normative commitment is a commitment that is based on moral grounds. He appeared driven by their personal values and obligations are based. The role of personal values in normative commitment shown by guilt when people tried to leave the organization. Robbins and Judge (2008: 101) defined normative commitment as an obligation to stay in an organization for reasons of moral or ethical. While Colquit, Lepine, and Wesson (2009: 690) defined normative commitment as a desire to remain a member of an organization because they feel obliged. Meanwhile, according to Allen and Mayer (1990: 217) defined normative commitment as commitment that arising from the value of employees themselves.

\section{RESEARCH METHODOLOGY}

This research was conducted at the primary school in Medan. The research was conducted from February until October 2016. The study was a quantitative research, the type of path analysis. The pattern of linkages between the work climate (X1), the effectiveness of the team (X2), job satisfaction (X3), and normative commitment (X4) on the performance of primary school principals (X5) is shown in Figure 1 below.

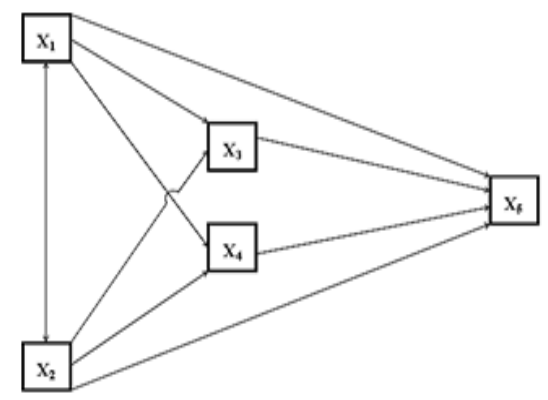

Figure 1. Research Paradigm 
The population in this study is all principals of primary schools in Medan, 435 persons. Determination of the number of samples and certain populations were developed from Isaac and Michael are on the total sample of 272 people. In this study there were five variables, namely: the performance of the principal, work climate, team effectiveness, job satisfaction, and normative commitment. The performance of school principals is the behavior shown principals as leaders and decision makers in mobilizing and directing subordinates to continue working properly achieve school goals, demonstrated through: planning, organizing, and monitoring. Working climate is a working atmosphere that is formed in an organization involving all the schools in achieving a common goal, which is demonstrated through: a sense of responsibility, standards of quality of work, a reward for the achievement of the work, a sense of brotherhood, team spirit, sense of the organizational system, and how to communicate. The team effectiveness is a joint activity of the working team within the organization to achieve school goals with precise, which is indicated by: having a desire for a common goal, the evaluation of the performance properly, mutual dependence and belonging, applying knowledge to team goals, and participate in team decisions.

Job satisfaction is a reflection of the feeling of the principal related to their job at the school based on the objectives set, which are indicated by: a challenging job, a decent reward, working conditions that support, coworker support, and personality suitability to the job. Normative commitment is the desire of a principal to continue to survive and work voluntarily achieve the objectives of the school, which is indicated by: stay in an organization, care about the organization, enjoys work, and believe in the mission of the organization.

Description of Data

\section{DISCUSSION}

Summary descriptive analysis of calculation results are presented in Table 1 below.

Table 1 Summary Calculation of Descriptive StatisticsResults

\begin{tabular}{|l|l|l|l|l|l|l|}
\hline \multirow{2}{*}{ No } & \multirow{2}{*}{ Statistics } & \multicolumn{4}{|l|}{ Variable Data } & $\mathbf{X}_{\mathbf{3}}$ \\
\cline { 3 - 7 } & & $\mathbf{X}_{\mathbf{1}}$ & $\mathbf{X}_{\mathbf{2}}$ & $\mathbf{X}_{\mathbf{3}}$ & $\mathbf{X}_{\mathbf{4}}$ & $\mathbf{X}_{\mathbf{5}}$ \\
\hline 1 & Maximum & 147 & 137 & 140 & 133 & 138 \\
\hline 2 & Minimum & 54 & 46 & 60 & 58 & 63 \\
\hline 3 & Modus & 126,551 & 70,708 & 114,625 & 103,684 & 116,000 \\
\hline 4 & Median & 119,500 & 73,080 & 111,571 & 101,375 & 113,000 \\
\hline 5 & Mean & 112,588 & 76,695 & 109,938 & 100,478 & 111,596 \\
\hline 6 & Standar Deviation & 23,291 & 20,172 & 15,121 & 16,878 & 16,420 \\
\hline
\end{tabular}

Information:

$\mathrm{X} 1$ = Working Climate

$\mathrm{X} 2$ = Team Effectiveness

X3 = Job Satisfaction

$\mathrm{X} 4$ = Normative commitment

X5 = Performance of Principal

\section{DISCUSSION OF RESULTS}

Based on the value of the correlation coefficients and path coefficient obtained from the calculation, then the next calculation of direct and indirect effects of exogenous variables on endogenous variables as Table 2 below.

Table 2 Summary Calculation of Path Coefficient, Direct Effect, Indirect Effect, Total Effect, and Non Path

\begin{tabular}{|l|l|l|l|l|l|l|l|l|}
\hline \multirow{2}{*}{ Model } & $\begin{array}{l}\text { Exogenous } \\
\text { variable to } \\
\text { variable } \\
\text { Endogenous }\end{array}$ & Direct & $\begin{array}{l}\text { Indirect } \\
\text { through } \\
\mathbf{X}_{3}\end{array}$ & $\begin{array}{l}\text { Indirect } \\
\text { through } \\
\mathbf{X}_{4}\end{array}$ & $\begin{array}{l}\text { Total } \\
\text { Effect }\end{array}$ & $\mathbf{U}$ & $\mathbf{S}$ & \\
\hline I & $\mathrm{X}_{1}$ to $\mathrm{X}_{3}$ & 0,174 & - & - & 0,174 & 0,042 & - & 0,216 \\
& $\mathrm{X}_{2}$ to $\mathrm{X}_{3}$ & 0,210 & - & - & 0,210 & 0,035 & - & 0,245 \\
\hline II & $\mathrm{X}_{1}$ to $\mathrm{X}_{4}$ & 0,295 & - & - & 0,295 & 0,047 & - & 0,342 \\
& $\mathrm{X}_{2}$ to $\mathrm{X}_{4}$ & 0,237 & - & - & 0,237 & 0,059 & - & 0,296 \\
\hline III & $\mathrm{X}_{1}$ to $\mathrm{X}_{5}$ & 0,133 & 0,039 & 0,104 & 0,276 & 0,033 & - & 0,309 \\
& $\mathrm{X}_{2}$ to $\mathrm{X}_{5}$ & 0,168 & 0,044 & 0,090 & 0,302 & 0,026 & - & 0,328 \\
& $\mathrm{X}_{3}$ to $\mathrm{X}_{5}$ & 0,180 & - & - & 0,180 & - & 0,155 & 0,335 \\
\hline
\end{tabular}


The Effect of Working Climate, Team Effectiveness, Job Satisfaction and Normative Commitm...

\begin{tabular}{|l|l|l|l|l|l|l|l|l|}
\hline & $\mathrm{X}_{4}$ to $\mathrm{X}_{5}$ & 0,303 & - & - & 0,303 & - & 0,146 & 0,449 \\
\hline
\end{tabular}

\section{The Direct Effect Working Climate On The Job Satisfaction}

Structural equation prediction of job satisfaction on the working climate is $\mathrm{X} 3=0.174 \mathrm{X} 1$. Working climate provide direct influence on job satisfaction of the principals at 0.174 . While the influence of non path of 0.042. Thus to improve the job satisfaction of the primary school principals can be done by improving the working climate of primary school in Medan. There is a $17.4 \%$ working climate affect the job satisfaction of the primary school principals, while the influence of non path is $4.2 \%$. These findings indicate an increase in the working climate is instrumental in efforts to increase job satisfaction of primary school principals. The results also support the theory advanced Blum in Aryanti (2003) that job satisfaction is the general attitude that the result of some special attitude towards factors work, adjustment and social relationships of individuals out of work. Gibson, John, and James (2000) reported job satisfaction is a positive attitude and can also negatively owned by individuals against various aspects of work, workplace and relationships with co-workers.

The results of subsequent studies show the various dimensions of work climate known that dimensions team spirit provide the largest contribution to the increase in the working climate, while the dimension of fraternity provides the smallest contribution in improving the work climate. Thus in order to optimize the working climate influence on job satisfaction has to do improve on the dimension of fraternity.

\section{The direct effect on Job Satisfaction Team Effectiveness}

Structural equation prediction of job satisfaction on the team effectiveness is $\mathrm{X} 3=0.210 \mathrm{X} 2$. Team effectiveness provides a direct effect on job satisfaction of primary school principals at 0.210 . While the influence of non path 0,035 . Thus, to improve the job satisfaction of primary school principals can be done by increasing team effectiveness of primary school principalsin Medan. There is a $21.0 \%$ team effectiveness variables affect the job satisfaction of the primary school principals, while the influence of non path is 3.5\%. These findings indicate an increase in the effectiveness of the team ia instrumental in efforts to increase job satisfaction of primary school principals.

The results also support the theory from Colquitt, Jeffery, and Michael (2009: 9) that job satisfaction of someone in the organization can be influenced by the effectiveness of existing teams in organizations. The results of subsequent studies show the some dimension of team variable, it's known that evaluation and performance system dimensions gives the largest contribution to the increase in the team effectiveness, while the dimensions of participate in the team's decision provides the smallest contribution in increasing the effectiveness of the team. Thus in order to optimize the effect on job satisfaction of the team's effectiveness should be improved on the dimensions participate in the team's decision. Participate in team decisions in building the team's effectiveness is needed, given the effectiveness of the existing team in school grow and develop in line with the needs of each school community in an opinion for future school success.

\section{Direct Impact of Working Climate On Normative Commitment}

Structural equation prediction normative commitment on the working climate is $\mathrm{X} 4=0.295 \mathrm{X} 1$. Working climate directly affect the normative commitments primary school principals at 0.295 . While the influence of non path is 0,047 . Thus to improve the normative commitment primary school principals can be done by improving the working climate primary school principalsin Medan. There is a $29.5 \%$ working climateaffect the normative commitment primary school principals, while the influence of non path of $4.7 \%$. These findings indicate an increase in the working climate was instrumental in improving the normative commitment primary school principals. The results of subsequent studies show the various dimensions of work climate variables known the dimensions of team spirit provide the largest contribution to the increase in the working climate, while the dimension of fraternity provides the smallest contribution in improving the working climate. Thus in order to optimize the working climate influence on normative commitment through improving working cilmate on the dimensions of fraternity.

\section{The direct effect of the Team Effectiveness On Normative Commitment}

Structural equation prediction normative commitment on the effectiveness of the team is $\mathrm{X} 4=0.237$ $\mathrm{X} 2$. Team effectiveness variables directly affect the normative commitments primary school principals at 0.237 . While the influence of non path is 0.059 . Thus, to improve the normative commitment primary school principals can be done by increasing team effectiveness primary school principals in Medan. There are $23.7 \%$ of normative commitment primary school principals influenced by the effectiveness of the team, while there is still the influence of non path of 5.9\% which can improve normative commitment primary school principals in Medan. These findings indicate an increase in the effectiveness of the team was instrumental in improving the normative 
commitment primary school principals. The results Ullah and Dong (2013) and Lischshinsky and Vicki (2010) revealed that there is effect of the effectiveness of the team to one's commitment. The results of subsequent studies show some dimension of the team effectiveness variable known that evaluation and performance evaluation system gives the largest contribution to the increase in the effectiveness of the team, while the dimensions participate in the team's decision provides the smallest contribution in increasing the effectiveness of the team. Thus in order to optimize the effect of the team's effectiveness on normative commitment is through improving on the dimensions of participate in the team's decision. Participate in team decisions in the context of improving the effectiveness of the team at the school can be improved by asking the teacher and employee to seek methods or new ideas in achieving the goals of the school.

\section{The Direct Impact Working Climate on Performance}

Structural equation prediction working climate on performance in X5 =0,276 X1. Working climate variables directly affect the performance of 0,276 . While the influence of non path at 0,033 . Thus to improve the performance can be done by improving the working climate primary school principals. There is $27.6 \%$ working climate influence on performance, while there is still the influence of non path of $3.3 \%$. These findings indicate an increase in the working climate was instrumental in improving performance. The results Popa (2011), and Poonam Rani (2014), and Jayaweera (2015) showed there is effect of working climate on teacher performance. The results of subsequent studies show the various dimensions of working climate known that dimensions of team spirit provide the largest contribution to increase working climate, while the dimension of fraternity provides the smallest contribution in improving the working climate. Thus in order to optimize the working climate influence on the performance of the principal must be carried out improving on the dimensions of fraternity. Fraternity in the context of improving the working climate in schools can be improved by supporting the idea of teachers and employees who want to advance the school.

\section{The Direct Effect of Team Effectiveness on the Performance}

Structural equation prediction ofteam effectiveness on the performance is $\mathrm{X} 5=0,302 \mathrm{X} 2$. Team effectiveness (X2) directly affect the performance at 0,302. The influence of non path is 0.026 . Thus to improve the performance can be done by increasing team effectiveness at primary school in Medan. There is $30.2 \%$ the influence of the team's effectivenesson the performance, while there is still the influence of non path of $2.6 \%$. These findings indicate that an increasing the effectiveness of the team was instrumental in improving the performance.The results of the study Chen, et al (2011), Somech, et al (2009), Rico, et al (2011), which revealed there is influence of team effectiveness on someone'sperformance in the organization. The results also support the theory by Rivai and Deddy (2011) that a team is a group of people with complementary skills and be committed to the same mission, achievement of performance, and approaches where they are interdependent with each other.

The results of subsequent studies show the effectiveness of some dimensions of team effectiveness variable known that dimensions of evaluation and performance system gives the largest contribution to the increase in the effectiveness of the team, while the dimension of participate in the team's decision provides the smallest contribution in increasing the effectiveness of the team. Thus in order to optimize the effect of the team's effectiveness on the performance of the principal can be done by improving on the dimensions of participate in the team's decision.

\section{The Direct Effect of Job Satisfaction on Performance}

Structural equation prediction of job satisfaction on performance is the $\mathrm{X} 5=0.180 \mathrm{X} 3$. Job satisfaction (X3) provide direct influence on the performance at 0.180 . The influence of non path is 0.155 . Thus to improve the performance can be done by increasing job satisfaction of primary school principals in Medan. There is $18.0 \%$ effect of job satisfaction on performance, while there are still non path effect of $15.5 \%$. These findings indicate that an increasing in job satisfaction is instrumental in improving performance. Usop research results, et al (2013) and Ali and Abdulkadir (2015) there is effect of job satisfaction on performance. High job satisfaction is desired by principals because it can be associated with positive outcomes that they expect to school development. The results also support the theory put forward Colquitt, Jeffery, and Michael (2009: 9) and Robbins and Judge (2008: 404) said that the team usually works better than individuals when the tasks do require a lot of skill, opinions, and experience. The results of subsequent studies show the various dimensions of job satisfaction variables known thatappropriate reward dimensions give the largest contribution to increase the effectiveness of the team, while the dimensions of co-workers support provides the smallest contribution in increasing the effectiveness of the team. Thus in order to optimize the effect of job satisfaction on the performance of the principal, so must be carried out improve on the dimensions of the co-worker support.

\section{The Direct Effect Of Normative Commitment On Performance}


Structural equation prediction of normative commitment on performance is $\mathrm{X} 5=0,303 \mathrm{X} 4$. Normative commitment (X4) gives a direct effect on the performance of 0,303 . The influence of non pathis 0,146 . Thus to improve the performance can be done by improving the normative commitment of primary school principals. There is $30.3 \%$ effect of normative commitment onthe performance, while there are still non path effect of $14.6 \%$. These findings indicatedthat an increasing ofnormative commitment is instrumental in improving performance. The research result Shah (2012) and Mahmood et al (2100) revealed that there are effect of normative commitment on the performance. The results also support the theory by Greefield (1987) and Kreitner and Kinicki (2001: 75) that someone's performancein the organization is influenced by normative commitment in the organization. High normative commitment of principals indicated by the desire of principals to continue to work well within the rules set. The results of subsequent studies show the various dimensions of normative commitment variables known dimensions of enjoy the work provided the largest contribution in the improvement of normative commitment, while the dimensions of care for organizations gives the smallest contribution in the improvement of normative commitment. Thus in order to optimize the effect of the performance of the principal, so must be able to improve on the dimensions of the care for organization.

\section{Conclusion:}

\section{CONCLUSION, IMPLICATION AND SUGGESTION}

1. There is a significant positive effect of the working climate on normative commitment primary school principals in Medan. It means the better working climate also the better normative commitment of primary school principalsin Medan.

2. There is a significant positive effect of the team's effectiveness on normative commitment of primary school principals in Medan. It means the better team effectiveness also the better normative commitment primary school principals in Medan.

3. There is a significant positive effect of working climate on the performance of primary school principals in Medan. It means the better working climate also the better the performance of primary school principals in Medan.

4. There is a significant positive effect of team effectiveness on the performance of primary school principals in Medan. It means the better the team effectiveness, the better the performance of primary school principals in Medan.

5. There is a significant positive effect of working climate on job satisfaction of of primary school principals in Medan. It means the better working climate also the better the job satisfaction of of primary school principals in Medan.

6. There is a significant positive effect of job satisfaction on performance of primary school principals in Medan. It means the better $\mathrm{t}$ job satisfaction of the team then the better the performance of primary school principalsin Medan.

7. There is a significant positive effect of job satisfaction on team effectiveness of of primary school principalsin Medan. It means the better job satisfaction then the better the team effectiveness of the of primary school principalsin Medan.

8. There is a significant positive effect of normative commitment on the performance of of primary school principalsin Medan. It means the better normative commitment then the better the performance of primary school principalsin Medan.

\section{Implication:}

\section{Implications of Education Office of Medan:}

a. Maintaining of ongoing working climate and strived the increasing of working climate by maintaining of team spirit dimension at the school. One effort that can be done is to organize activities at partner schools that requires all school members are actively involved in.

b. Maintaining of ongoing team effectiveness and improvement pursued by maintaining dimensions of performance and evaluation system in the school. One effort that can be done by the principal is to provide opportunities to all heads of partner schools to provide ideas in a meeting in disctrict education office to improve the quality of education.

c. Maintaining of ongoing job satisfaction andimprovement pursued by maintaining dimenasion of appropriate reward. One effort that can be done is to create a working group of primary school principals who can coordinate their work and sharing development activities in their respective schools.

d. Maintaining of ongoing normative commitment and improvement pursued by maintaining the dimensions of the enjoy the work. One effort can be done by principal is always focus on the development of knowledge and skills of school principals, by having the primary school principals in leadership school development training. 
The Effect of Working Climate, Team Effectiveness, Job Satisfaction and Normative Commitm...

\section{Implications for School Principals}

a. Improved working climate in achieving good performance of primary school principals can be done by increasing the dimension of brotherhood among the school community. By increasing the dimension of fraternity, working climate will become even better and affect the performance of primary school principalsto be better than before. One effort that can be done is to organize activities that involve the entire school community.

b. Enhancing the effectiveness of the team in achieving a good performance of primary school principals can be done by increasing the dimensions of participating in the team's decision. By increasing the dimension of participating in the team's decision, team effectiveness will become better and affect the performance of primary school principals to be. One effort that can be done by the principal is by giving chance for the entire school community to provide ideas directed to development a better school in annually working meetings.

c. Increasing job satisfaction in achieving good performance primary school principals can be done by increasing the dimensions of a co-worker support. By increasing the dimensions of the co-worker support, job satisfaction will become even better and affect the performance of primary school principals to be better. One effort that can be done is by delegating certain tasks to some teachers and staff in managing projects or activities of school development.

d. Improving normative commitment to achieve a good performance of primary school principals that can be done by increasing the dimensions of care to the organization. By increasing the dimensions of care to the organization, normative commitment will become better and affect the performance of primary school principals to be better. One effort that can be done by principal is always focus on the development of the school, following training of leadership skills development.

\section{Suggestion:}

1. To the Medan City Government in this regard Department of Education should treat primary school principals as an academic position, so that in every appointment of principals on the basis of professionalism. Elements readiness of a school principal should be based on ability in planning, organizing, and monitoring. It is recommended to Department of Education to perform both written and oral tests in view of the ability of a candidate school principal before being appointed as principal.

2. Primary school principals should continue to train themselves to improve their performance. One of them actively involved in some training the ability to manage the school. In addition, the principal must be willing to continue their education to a higher level (master of education so that their knowledge can grow continiously in line with changes in modern times).

3. Keep in the principal's role in promoting a conducive working environment in the school, the effectiveness of team elected in charge of ensuring the school program reached target, cultivate contentment himself while working at the school, ensuring normative commitment that has not changed when there are offers better job.

4. Given some limitations of this study, it is advisable for researchers to conduct further research to find results proving that the performance can be affected by other exogenous variables outside the work climate, team effectiveness, job satisfaction, and normative commitment; which have an asymmetrical relationship with each other to be obtained dominant variables that determine changes in the performance of primary school principals. Need reproduced sample that is representative of primary school principals in Medan so that generalizations wider coverage to overcome these limitations.

\section{REFERENCEES}

[1]. Ali, Ali Yassin Sheikh dan Abdulkadir Mohamud Dahie. 2015. "Leadership Style and Teacher Job Satisfaction: Empirical Survey from Secondary Schools in Somalia". Research on Humanities and Social Sciences - Vol.5, No.8, 2015

[2]. Allen, N.J., andJP. Meyer. 1990. "The Measurement and Antecedents of Affective Continuance, and Normative Commitment to Organization”. Journal of Occupational

[3]. Anshori. 2003. Kamus Inggris Indonesia. Jakarta: Gramedia

[4]. Aryanti, SWD. 2003. "Pengaruh Lingkungan Kerja Terhadap Kepuasan Kerja Karyawan". Jurnal Ilmiah Ekonomi \& Kewirausahaan, Vol. 01, No. 04, Agustus 2003

[5]. Chen, Charlie C.,Jiinpo Wu, Samuel C. Yang, dan Hsin-Yi Tsou. 2011. "Importance of Diversified Leadership Roles in Improving Team Effectiveness in a Virtual Collaboration Learning Environment". Educational Technology \& Society, 11 (1), 304-321

[6]. Colquitt, Jason A., Jeffery A.Lepine, danMichael J.Wesson. 2009. Organizational Behavior, Improving Performance and Performance and Commitment in the Workplace. New York: McGraw-Hill

[7]. Gibson, Jamies L., John M. Ivancevich, dan James H. Donnelly. 2000. Organisasi. Jilid 2. Edisi kedelapan Alih bahasa Ir. Nunuk Adiarni MM. Jakarta: Binarupa Aksara 
The Effect of Working Climate, Team Effectiveness, Job Satisfaction and Normative Commitm...

[8]. Hasibuan, S.P. Malayu. 1999Manajemen Dasar Pengertian dan Masalah. Jakarta: Gunung Agung

[9]. Jayaweera, Thushel. 2015. "Impact of Work Environmental Factors on Job Performance, Mediating Role of Work Motivation: A Study of Hotel Sector in England". International Journal of Business and Management; Vol. 10, No. 3; 2015

[10]. Lischshinsky, Orly Shapira dan Vicki Aziel. 2010. "Team Culture Perceptions, Commitment, and Effectiveness: Teamwork Effects". Educational Practice and Theory - Vol. 32, No. 2, 2010

[11]. Kreitner, Robert and Kinicki Angelo. 2001.Organizational Behavior. New York:Irwin Mc Graw-Hill, Int. Edition

[12]. Mahmood, Azhar., Saira Nudrat, Muhammad Musaud Asdaque, Allaha Nawaz, dan Nazir Haider. 2011. "Job Satisfaction of Secondary School Teachers: A Comparative Analysis of Gender, Urban and Rural Schools". Asian Social Science - Vol. 7, No. 8; August 2011

[13]. Minner, Jhon B. 1997. Industrial Organizational Psychology. New York: McGraw-Hill

[14]. Mulyasa, E. 2011.Menjadi Kepala Sekolah Profesional. Bandung: Rosdakarya

[15]. Pace, R. Wayne. Faules, Don F. 2006. Komunikasi Organisasi - Strategi Meningkatkan Kinerja Perusahaan. Bandung: Remaja Rosdakarya

[16]. National Education Minister Regulation No. 13 of 2007 on the Standards for School/Madrasah(Peraturan Menteri Pendidikan Nasional Nomor 13 Tahun 2007 tentang Standar Kepala Sekolah/Madrasah).

[17]. Popa, Brîndusa Maria. 2011. "The Relationship Between Performance and Organizational Climate". Journal of Defense Resources Management, No. 2 (2) / 2011

[18]. Rani, Reena dan Poonam Rani . 2014. "Influence of Organizational Climate of Elementary Schools On Job Satisfaction of Elementary Teachers". International Journal of Science, Environment and Technology, Vol. 3, No 2, 2014, $652-658$

[19]. Rico, Ramón., Carlos María Alcover de la Hera, dan Carmen Tabernero. 2011. "Work Team Effectiveness, A Review of Research From The Last Decade (1999-2009)". Psychology in Spain, 2011, Vol. 15. No 1, 57-79

[20]. Rivai, Veithzal, dan DeddyMulyadi. 2011. Kepemimpinan dan Perilaku Organisasi. Jakarta: RajaGrafindo Persada

[21]. Robbins, Stephen P. 2007. Perilaku Organisasi. Alih Bahasa: Hadiana Pudja Atmaka. Jakarta: Prehalindo

[22]. Robbins, Stephen P. dan Judge Timothy. 2008. Perilaku Organisasi. Konsep, Kontroversi dan Aplikasi. Jakarta: Prehalindo

[23]. Shah, Madiha. 2012. "The Impact of Teachers' Collegiality on their Organizational Commitment in High- and Low-Achieving Secondary Schools in Islamabad, Pakistan”. Journal of Studies in Education 2012, Vol. 2, No. 2

[24]. Smith. 1983. Organizational Citizenship Behavior; its Nature and Antecedents, Journal of Aplied Psycholog

[25]. Somech, Anit., Helena Syna Desivilya, dan Helena Lidogoster. 2009. "Team Conflict Management and Team Effectiveness: The Effects of Task Interdependence and Team Identification". Journal of Organizational Behavior, 30, 359-378 (2009)

[26]. Steers, Richard M. dan Porter W. Lymann. 2003. Motivation and Work Behavior. New York: McGrawHill Inc

[27]. Ullah, Ullah S. M. Ebrahimdan Dong Soo Park. 2013. "Shared Leadership and Team Effectiveness: Moderating Effects of Task Interdependence". African Journal of Business Management - Vol. 7(40), pp. 4206-4220, 28 October, 2013

[28]. Usop, Annierah Maulana.,Doctor Kamarulzaman Askandar, Maeda Langguyuan-Kadtong, Datu Amir Sajid Onotan Usop. 2013. "Work Performance and Job Satisfaction among Teachers". International Journal of Humanities and Social Science, Vol. 3 No. 5; March 2013

[29]. Wahjosumidjo. 2011. Kepemimpinan Kepala Sekolah: Tinjauan Teoretik dan Permasalahannya. Jakarta: RajaGrafindo Persada

[30]. Wirawan. 2008. Budaya dan Iklim Organisasi. Jakarta: Salemba Empat 